\title{
RIPITABILITAS KECEPATAN LARI DAN TINGGI PUNDAK ANAK KUDA PACU UMUR BERBEDA PADA KETURUNAN PEJANTAN "MANGUNI MAKASIOW" DENGAN METODE KORELASI DALAM KLAS (Intraclass corelation)
}

\author{
Sitty Fatimah S. Ambo, S. Adiani, U. Paputungan dan J. Paat \\ Fakultas Peternakan Universitas Sam Ratulangi, Manado 95115
}

\begin{abstract}
ABSTRAK
Penelitian ini bertujuan untuk mengetahui nilai ripitabilitas kecepatan lari dan tinggi pundak anak kuda pacu umur berbeda pada keturunan pejantan Manguni Makasiouw dengan metode korelasi dalam klas (Intraclass Corelation). Materi yang digunakan yaitu data kecepatan lari dengan berbagai jarak tempuh hasil perlombaan pacuan kuda di Sulawesi Utara dan Kejuaraan Nasional (Kejurnas) persatuan olahraga berkuda seluruh Indonesia (PORDASI). Data kecepatan lari dianalisis menggunakan metode analisis ragam (ANOVA) dan diuji lebih lanjut kemudian untuk mendapatkan nilai ripitabilitas. Berdasarkan hasil penelitian menunjukkan bahwa kecepatan lari anak kuda pacu yang tertinggi terdapat pada kuda pacu umur lima tahun dan yang paling rendah pada anak kuda pacu umur dua tahun, sedangkan tinggi badan anak kuda pacu umur 4 tahun lebih tinggi dibandingkan umur 2, 3 dan 5 . Nilai Ripitabilitas pada penelitian ini tergolong rendah yaitu di bawah 0,10 , yang masingmasing berkisar 0,029-0,047 (kecepatan lari) dan 0,029-0,05 (tinggi pundak). Nilai korelasi antara sifat kecepatan lari dan tinggi pundak pada umur 2-5 tahun memiliki nilai korelasi yang sangat tinggi $(0,760-0,961)$ yang menunjukkan bahwa semakin tinggi ukuran
\end{abstract} badan akan semakin tinggi pula tingkat kecepatan lari seekor kuda.

Kata Kunci: Kuda pacu, ripitabilitas, kecepatan lari, tinggi badan, umur berbeda.

ABSTRACK

SPEED AND BODY HEIGHT REPEATABILITIES OF RACING HORSE AT DIFFERENT AGE IN OFFSPRING FROM "MANGUNI MAKASIOUW" MALE PARENT WITH INTRACLASS CORRELATION . This study was conducted to determine the repeatability values of speed and body height at different ages of the offspring from "Manguni Makasiouw" male parent using intraclass correlation method. Data used in this study were the records of speed to run with various distance of race horse resulting from racehorse competition in North Sulawesi and national PORDASI competition. Running speed data were tabulated using the method of analysis of variance process to obtain the values of repeatabilities. Based on the research and discussion, running speed of racehorse was the highest in the age of five years old and the lowest in the age of two years old. The repeatability values in this study were 
relatively low, ranging from 0.029-0.047 (running speed) and from 0.029-0.05 (body height). The value of the correlation between running speed and body height at age 2-5 years had high correlation values (0.760 to 0.961), indicating that the higher the body height, the higher the level of horse running speed.

Keywords: Racing Horses, repeatability, speed, body height, different Ages.

\section{PENDAHULUAN}

Kuda pacu Indonesia merupakan ternak lokal Indonesia yang telah beradaptasi dengan baik di lingkungan Indonesia. Kuda tersebut memiliki potensi untuk dikembangkan dengan mempertimbangkan sektor ekonomi dan budaya yang tidak dapat dilepaskan dari peran pemulia dalam proses pengembangannya. Kuda pacu yang bermutu tinggi memiliki nilai ekonomi tersendiri, karena peningkatan kecepatan pacu yang berkorelasi dengan harga jual.

Kuda pacu Indonesia merupakan kuda hasil grading-up kuda lokal sumba dengan kuda pacu unggul Thoroughbred yang membentuk "Bangsa Baru" yang telah beradaptasi baik dengan lingkungan Indonesia sehingga dianggap sebagai kuda lokal. Metode seleksi merupakan upaya pemuliaan untuk meningkatkan kecepatan pacu kuda lokal Indonesia, sehingga karakteristik kuda lokal Indonesia dapat dipertahankan. Salah satu parameter genetik yang diperlukan untuk program seleksi kearah sifat kecepatan kuda pacu adalah ripitabilitas.

Salah satu penilaian performa kuda pacu yang baik adalah dengan melihat kecepatan kuda pada jarak lari yang ditempuh. Nilai kecepatan yang baik menjadi lebih baik lagi saat kecepatan tersebut dapat dipertahankan. Sifat kemampuan mempertahankan kecepatan berlari dapat terlihat dari nilai ripitabilitas sifat tersebut. Nilai ripitabilitas dapat menggambarkan proporsi keunggulan suatu sifat dari ternak Kuda Pacu Indonesia yang penting untuk diteliti sebagai upaya untuk menyeleksi pejantan yang unggul (Astuti, 2011).

Sulawesi Utara adalah salah satu dari beberapa daerah di Indonesia yang memiliki populasi kuda dengan berbagai macam pemanfaatan, seperti untuk menarik bendi atau delman, tunggangan dan pacuan.

\section{MATERI DAN METODE PENELITIAN}

Materi penelitian terdiri dari kelompok umur yang berbeda yaitu umur 2 sampai 5 tahun dengan jumlah sampel 202, kuda jantan 132 dan kuda betina 70. Data kecepatan lari dengan berbagai jarak 
tempuh hasil perlombaan pacuan kuda di Sulawesi Utara dan kejuaraan Nasional PORDASI. Informasi yang tersedia meliputi nama kuda, nama induk pejantan, nama pemilik, nama event, waktu tempuh lomba, selisih jarak finish dengan kuda peserta sebelumnya, dan waktu pelaksanaan lomba. Informasi dari Stewar pacuan Bapak Vecky Momuat ini dirangkum ke dalam tabel agar mudah dipelajari. Variabel yang diamati dalam penelitian ini adalah : (1) Kecepatan Lari; (2) Ripitabilitas; (3) Tinggi Pundak; (4) Korelasi.

Data kecepatan lari dianalisis menggunakan metode analisis ragam (ANOVA) dan diuji lebih lanjut kemudian untuk mendapatkan nilai ripitabilitas. Data yang sama juga digunakan untuk mendapatkan nilai korelasi antara kecepatan lari dengan tinggi badan kuda yang diamati. Pengelompokan dan pentabulasian data dilakukan dengan menggunakan program Excell Microsoft Office 2007. Pengolahan data dengan metode analisis ragam dan perhitungan nilai korelasi dilakukan melalui program excel MS office 2007. Model rancangan percobaan berdasarkan Becker (1968) yaitu:

$$
Y_{i k}=\mu+a_{i}+e_{i k}
$$

Keterangan :
$\mathrm{Y}_{i k} \quad=$ pengukuran ke- $\mathrm{k}$ pada individu

ke-1

$\mu \quad=$ nilai tengah umur

$\alpha_{i} \quad=$ pengaruh individu ke-1

$e_{i k} \quad=$ pengeruh lingkungan tak terkontrol dan atribut deviasi genetik individu

Pendugaan nilai ripitabilitas dihitung antara individu-individu menggunakan rumus (Becker, 1968) :

$$
\begin{gathered}
\mathrm{R}=\frac{\sigma_{\mathrm{w}}^{2}}{\sigma_{\mathrm{w}}^{2}+\sigma_{\mathrm{e}}^{2}} \\
\sigma_{e}^{2}=\mathrm{MS}_{\mathrm{e}} \operatorname{dan} \sigma_{\mathrm{w}}^{2}=\frac{\mathrm{MS}_{\mathrm{w}}-\mathrm{MS}_{\mathrm{e}}}{\mathrm{k}_{1}}
\end{gathered}
$$

Keterangan :

$\mathrm{R}=$ ripitabilitas

$\sigma_{w}^{2} \quad=$ ragam kecepatan pacu antara individu-individu yang diamati

$\sigma_{\mathrm{e}}^{2}=$ ragam kecepatan pacu berdasarkan pengukuranpengukuran dalam individu yang diamati

$M S_{w} \quad=$ kuadrat tengah kecepatan pacu

$M S_{e}=$ kuadrat tengah individu yang diamati

$k_{i} \quad=$ jumlah pencatatan atau ulangan

\section{HASIL DAN PEMBAHASAN}

Kecepatan lari kuda pacu Minahasa yang diamati pada penelitian ini disajikan pada Tabel 1. Berdasarkan Tabel 1 secara umum kecepatan lari kuda pacu baik pada jantan maupun betina semakin meningkat seiring dengan penambahan umur. Hal ini sesuai dengan pernyataan Hintz (1980) bahwa pada kuda Thoroughbred di Amerika secara umum puncak performa pacu dicapai pada umur empat tahun. 
Tabel 1. Rataan Kecepatan Lari (m/detik) Kuda Pacu Jantan dan Betina pada Berbagai Kelompok Umur

\begin{tabular}{lllll}
\hline Jenis kelamin & \multicolumn{4}{c}{ Umur (Tahun) } \\
\hline \multirow{0}{r}{} & \multicolumn{1}{c}{2} & \multicolumn{1}{c}{3} & \multicolumn{1}{c}{4} \\
& $6,8723 \pm 5,241$ & $5,4168 \pm 3,597$ & $7,6155 \pm 4,867$ & $9,0549 \pm 5,467$ \\
& $(76,25 \%)$ & $(66,40 \%)$ & $(63,90 \%)$ & $(60,37 \%)$ \\
& $(\mathrm{n}=36)$ & $(\mathrm{n}=31)$ & $(\mathrm{n}=38)$ & $(\mathrm{n}=27)$ \\
\hline+ & $7,3247 \pm 5,352$ & $9,6774 \pm 5,009$ & $8,9725 \pm 5,765$ & $9,1807 \pm 5,398$ \\
& $(73,06 \%)$ & $(51,75 \%)$ & $(64,25 \%)$ & $(58,70 \%)$ \\
& $(\mathrm{n}=15)$ & $(\mathrm{n}=19)$ & $(\mathrm{n}=21)$ & $(\mathrm{n}=15)$ \\
\hline Rataan & $7,0059 \pm 5,224$ & $7,0358 \pm 4,672$ & $8,0984 \pm 5,196$ & $9,0998 \pm 5,376$ \\
& $(74,56 \%)$ & $(66,40 \%)$ & $(64,16 \%)$ & $(59,07 \%)$ \\
& $(\mathrm{n}=51)$ & $(\mathrm{n}=50)$ & $(\mathrm{n}=59)$ & $(\mathrm{n}=42)$ \\
\hline
\end{tabular}

Keterangan: persen dalam kurung menyatakan koefisien keragaman, $n=$ jumlah individu.

Performa pacu seekor kuda dinilai dari kecepatan atau berapa cepat seekor kuda dapat berlari dan menyelesaikan pacuan.

Kecepatan lari oleh kuda pacu tersebut menunjukan tingkat variasi yang sangat tinggi dengan koefisien keragaman berkisar $58,7 \%$ - 76,25\%. Kurnianto (2009) menyatakan bahwa koefisien keragaman sangat tinggi jika melebihi $15 \%$ dan keragaman sangat rendah jika kurang dari $5 \%$.

Nilai rataan kecepatan lari pada kuda pacu yang tertinggi terdapat pada kuda pacu umur lima tahun sedangkan yang paling rendah terdapat pada kuda pacu yang berumur dua tahun. Hal ini terjadi karena kuda pacu pacu yang berumur dua tahun baru mulai mengikuti perlombaan dalam pacuan.

Koefisien keragaman terbesar pada sifat kecepatan lari kuda pacu dimiliki oleh kelompok kuda pacu umur dua tahun. Hal ini terjadi mungkin karena sifat pacu yang unggul dari kuda pacu tersebut telah terekspresi atau mendapat porsi waktu latihan dengan baik dari peternak atau pemilik kuda. Ekiz dan Kocak (2007) menyatakan bahwa umur dua tahun merupakan umur pertama atau umur awal kuda pacu Thoroughbred turut serta dalam pacuan resmi. Sesuai dengan Tabel 1 rataan kecepatan lari pada kuda pacu semakin bertambah umur kecepatan lari kuda tersebut semakin menurun. Hal tersebut terjadi mungkin akibat dari faktor ternak dan faktor lingkungan atau dari peternak dan pemilik kuda itu sendiri. Keragaman kecepatan lari ini menunjukkan bahwa baik kuda-kuda yang baru turut serta ataupun yang telah mengikuti lomba pacuan memiliki kecepatan yang tidak terlalu berbeda.

Data Tabel 1 menjelaskan bahwa pada penelitian ini kuda pacu yang 
berumur lima tahun memiliki kecepatan yang hampir seragam. Kecepatan lari pada umur tersebut tidak berbeda $(\mathrm{P}>0.05)$, koefisien keragaman yang lebih besar dimiliki oleh kelompok kuda pacu umur dua tahun. Kecepatan lari pada umur dua tahun tersebut sangat nyata $(\mathrm{P}<0,05)$, hal ini sangat mungkin terjadi karena banyak faktor, di antaranya pengalaman latihan atau program latihan dalam setiap individu kuda pacu, proses perkembangan perototan setiap individu kuda, program pemberian pakan dan manajemen, hubungan joki atau pelatih dengan setiap individu kuda pacu. Islami (2006) menyatakan bahwa pelatih memiliki peranan penting dalam menghasilkan kuda pacu yang berprestasi. Pelatih berpengalaman memiliki kemampuan menilai kelebihan dan kekurangan seekor kuda untuk kemudian menentukan bentuk latihan yang sesuai dengan kondisi kuda tersebut.

Tabel 2 menyajikan nilai ragam genetis dan lingkungan untuk sifat kecepatan lari kuda pacu Minahasa pada berbagai kelompok jenis kelamin. Data Tabel 2 menjelaskan bahwa kuda pacu jantan pengaruh lingkungan sementara kecepatan lari lebih tinggi dibandingkan dengan pengaruh genetis. Hal ini menunjukkan bahwa lingkungan sementara seperti pelatihan, masih lebih besar dari pada pengaruh genetis. Kuda pacu betina mampu beradaptasi diri sebagai kuda pacu berkecepatan tinggi. Kecepatan kuda pacu betina lebih tinggi dibandingkan kuda pacu jantan (Tabel 3). Pada kuda pacu betina pengaruh lingkungan sementara ditemukan lebih tinggi dibandingkan pengaruh genetis. Pengaruh lingkungan sementara seperti program pelatihan masih lebih besar dari pada pengaruh genetis.

Pelatihan yang dilakukan terus menerus pada kuda pacu jantan dan betina menghasilkan kuda-kuda pacu yang telah berprestasi untuk tampil sebagai kuda pacu berkecepatan tinggi. Faktor-faktor lingkungan lain berdasarkan Hintz (1980) yang meliputi umur pejantan (ayah),

Tabel 2. Rekapitulasi Hasil Uji-t Kecepatan Lari Kuda Pacu pada Berbagai Kelompok Umur

\begin{tabular}{ccc}
\hline Umur (Tahun) & Hasil Uji-t & Nilai P \\
\hline 2 & $* *$ & 0,002 \\
3 & tn & 0,112 \\
4 & th & 0,207 \\
5 & tn & 0,328 \\
\hline
\end{tabular}

Keterangan : ${ }^{*}=$ nyata, ${ }^{* *}=$ sangat nyata, $\mathrm{tn}=$ tidak nyata 
Tabel 3. Nilai $\sigma_{w}^{2}$ dan $\sigma_{e}^{2}$ Kecepatan Lari Kuda Pacu Jantan dan Betina

\begin{tabular}{llll}
\hline Sifat & Jenis kelamin & $\sigma_{w}^{2}\left(\sigma_{g}^{2}+\sigma_{L T}^{2}\right)$ & $\sigma_{e}^{2}\left(\sigma_{L S}^{2}\right)$ \\
\hline Kecepatan Lari & $\sigma^{\lambda}$ & 0,351 & 11,642 \\
& $\rho$ & 0,042 & 0,856 \\
\hline
\end{tabular}

Keterangan : $\sigma_{w}^{2}=$ Kuadrat Tengah antara Individu, $\sigma_{e}^{2}=$ Kuadrat Tengah antara Pengamatan dalam Individu, $\sigma_{G}^{2}=$ Ragam Genetis, $\sigma_{L T}^{2}=$ Ragam Lingkungan Tetap, $\sigma_{L S}^{2}=$ Ragam Lingkungan Sementara

musim saat ternak dilahirkan, lama bunting induk dan urutan kelahiran tidak mempengaruhi performa pacu kuda Thoroughbred. Faktor lain seperti umur dan jenis kelamin mempengaruhi performa pacu kuda Thoroughbred.

Pengukuran sifat kuantitatif berupa nilai dan rataan ukuran sifat tertentu seringkali belum memberikan gambaran sesungguhnya tentang potensi setiap kuda, sifat tersebut memiliki kecenderungan untuk berulang pada pengukuran berikutnya di masa mendatang (Astuti, 2011). Perhitungan tersebut berguna untuk mengetahui apakah sifat yang diamati merupakan sebuah ekspresi genetis atau hanya merupakan hasil dari pengaruh lingkungan sementara pada seekor atau sekelompok ternak. Kecenderungan pengulangan suatu sifat disebut dengan nilai Ripitabilitas seperti terlihat pada Tabel 4. Ripitabilitas (r) merupakan suatu pengukuran kesamaan antara pengukuran suatu sifat yang diukur berkali-kali pada ternak yang sama selama ternak tersebut hidup (Noor, 2008).

Nilai ripitabilitas suatu sifat ditentukan oleh keragaman komponenkomponen penyusunnya, yaitu komponen genetik yang terdiri atas gen aditif, dominan dan epistasis serta komponen lingkungan, baik yang bersifat permanen maupun sementara (Noor, 2008). Warwick et al. (1987) menyatakan bahwa pengaruh lingkungan permanen adalah semua pengaruh lingkungan yang bukan bersifat

Tabel 4. Nilai Ripitabilitas Kecepatan Lari dan Tinggi Pundak Kuda Pacu pada Jantan dan Betina.

\begin{tabular}{lcc}
\hline Sifat & Jenis Kelamin & Nilai Ripitabilitas (R) \\
\hline Kecepatan & 0 & 0,029 \\
& 0 & 0,047 \\
Tinggi Pundak & + & 0,029 \\
& 0 & 0,054 \\
\hline
\end{tabular}

Keterangan : $\mathrm{R}=$ Nilai Ripitabilitas 
genetik akan tetapi dapat mempengaruhi produktifitas seekor ternak selama hidupnya.

Tabel 4 nilai ripitabilitas menunjukkan secara umum nilai ripitabilitas kecepatan lari dan tinggi pundak pada kuda pacu Minahasa. yang diperoleh pada penelitian ini adalah nilai ripitabilitas yang rendah yaitu dibawah 0,10. Ripitabilitas kecepatan lari tertinggi yang diperoleh pada penelitian ini ditemukan pada kuda pacu betina. Hal tersebut terjadi karena kuda pacu betina telah dapat mengekspresikan diri dengan baik sebagai kuda pacu berkecepatan tinggi atau pengaruh peranan hormonhormon yang terkait perbedaan jenis kelamin dan pertumbuhan selain itu faktor lingkungan sementara tetap berpengaruh pada kecepatan lari kuda betina, seperti pelatihan (program latihan, hubungan joki dengan individu), dan manajemen pemeliharaan yang teratur (pakan, control penyakit, perkandangan, program pemuliaan).

Ripitabilitas tinggi badan pada kuda pacu Minahasa yang ditemukan pada penelitian ini adalah kuda pacu betina. Kuda pacu betina lebih tinggi dibandingkan kuda pacu jantan, dengan demikian sifat tinggi pundak pada kuda pacu merupakan suatu sifat yang akan diwariskan pada keturunannya dan sangat dipengaruhi oleh faktor genetis dan faktor lingkungan tetap. Noor (2008) menyatakan bahwa ripitabilitas dugaan maksimal nilai heritabilitas.

$$
\text { Tumer dan Young }
$$
menyatakan bahwa nilai ripitabilitas yang tinggi menandakan ternak mampu berproduksi dengan ukuran yang hampir sama setiap tahun. Ternak dinilai cenderung mendekati ukuran tertinggi secara konstan, tidak terpengaruh jumlah rataan ukuran yang mungkin berubah. Penelitian ini sedikit di atas Ekiz dan Kocak (2007) pada kuda Thoroughbred Turki $(0,28-0,40)$ hal ini mengindikasikan bahwa kuda pacu Indonesia memiliki daya pengulangan atau pewarisan sifat kecepatan lari yang lebih tinggi dari pada kuda Thoroughbred meskipun kecepatan lari kuda pacu Indonesia lebih rendah.

Tinggi pundak kuda pacu Minahasa yang diamati pada penelitian ini disajikan pada Tabel 5, yaitu rataan tinggi badan pada jantan dan betina pada berbagai kelompok umur. Variasi tinggi badan kuda pacu terlihat rendah dengan nilai koefisien keragaman hanya berkisar 2,02\% - 3,31\%. Jika koefisien keragaman lebih rendah dari 5\% maka variasinya sangat rendah (Kurnianto, 2009).

Tabel 5 di atas menjelaskan nilai rataan tinggi pundak pada kuda pacu. Pada penelitian ini bahwa rataan tinggi pundak yang besar ada pada kuda pacu yang berumur 4 tahun dibandingkan kuda pacu 
Tabel 5. Rataan Tinggi Pundak (cm) Kuda Pacu Jantan dan Betina pada Berbagai Kelompok Umur

\begin{tabular}{|c|c|c|c|c|}
\hline \multirow[t]{2}{*}{ Jenis Kelamin } & \multicolumn{4}{|c|}{ Umur (Tahun) } \\
\hline & 2 & 3 & 4 & 5 \\
\hline \multirow{3}{*}{ 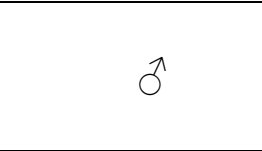 } & $147,605 \pm 4,887$ & $148,341 \pm 4,096$ & $149,697 \pm 4,498$ & $147,759 \pm 3,029$ \\
\hline & $(3,31 \%)$ & $(2,76 \%)$ & $(3,01 \%)$ & $(2,04 \%)$ \\
\hline & $(n=36)$ & $(n=31)$ & $(n=38)$ & $(n=27)$ \\
\hline \multirow{3}{*}{ q } & $148,506 \pm 3,364$ & $147,331 \pm 3,886$ & $145,352 \pm 3,382$ & $147,940 \pm 3,038$ \\
\hline & $(2,26 \%)$ & $(2,63 \%)$ & $(2,32 \%)$ & $(2,05 \%)$ \\
\hline & $(n=15)$ & $(n=50)$ & $(\mathrm{n}=21)$ & $(n=15)$ \\
\hline \multirow{3}{*}{ Rataan } & $147,282 \pm 4,530$ & $147,331 \pm 3,886$ & $145,352 \pm 3,382$ & $147,940 \pm 3,038$ \\
\hline & $(3,07 \%)$ & $(2,70 \%)$ & $(3,11 \%)$ & $(2,02 \%)$ \\
\hline & $(n=51)$ & $(n=50)$ & $(n=59)$ & $(n=42)$ \\
\hline
\end{tabular}

Keterangan: persen dalam kurung menyatakan koefisien keragaman, $n=$ jumlah individu.

yang berumur 2, 3 dan 5 tahun. Sedangkan yang paling rendah diperoleh pada kuda pacu yang berumur 5 tahun. Hal itu terjadi kemungkinan dipengaruhi oleh beberapa faktor misalnya oleh faktor genetis dari induknya entah dari induk jantan atau induk betina.

Tinggi pundak kuda pacu dapat dilihat pada Tabel 5. Hasil uji-t pada umur 3, 4 dan 5 tidak berbeda atau memiliki nilai $(\mathrm{P}>0,05)$ sedangkan pada umur 2 tahun perbedaan tinggi badan sudah nampak yang memiliki nilai $(\mathrm{P}<0,05)$. Perbedaan tersebut dapat terjadi karena pengaruh hormon yang berhubungan dengan pertumbuhan yang disebabkan perbedaan jenis kelamin. Jenis kelamin memainkan peranan penting dalam pertumbuhan seekor ternak.

Penampakan ekspresi potensi ternak secara mendasar dipengaruhi oleh dua faktor utama yang saling terkait satu dengan yang lainnya, yaitu faktor genetis dan faktor lingkungan termasuk didalamnya manajemen pemeliharaan secara menyeluruh. Lingkungan dan penanganan manajemen yang memadai atau sesuai dengan kebutuhan ternak tidak akan memberikan produksi yang berkualitas.

Tabel 6. Rekapitulasi Hasil Uji-t Tinggi Pundak Kuda Pacu pada Berbagai Kelompok Umur

\begin{tabular}{ccc}
\hline Umur & Hasil Uji-t & Nilai P \\
\hline 2 & $* *$ & 0,000 \\
3 & tn & 0,146 \\
4 & tn & 0,178 \\
5 & tn & 0,160 \\
\hline
\end{tabular}

Keterangan : $* *=$ sangat nyata, $*=$ nyata, $\mathrm{tn}=$ tidak nyata 
Tabel 7. Nilai $\sigma_{w}^{2}$ dan $\sigma_{e}^{2}$ Tinggi Pundak Kuda Pacu Jantan dan Betina

\begin{tabular}{|c|c|c|}
\hline Jenis Kelamin & $\sigma_{w}^{2}\left(\sigma_{g}^{2}+\sigma_{L T}^{2}\right)$ & $\sigma_{e}^{2}\left(\sigma_{L S}^{2}\right)$ \\
\hline \multirow{2}{*}{ Tinggi Badan } & 12,464 & 417,23 \\
\hline & 15,430 & 26,947 \\
\hline
\end{tabular}

Tabel 8. Korelasi antara Kecepatan Lari dan Tinggi Pundak Kuda Pacu Minahasa Jantan dan Betina pada Berbagai Umur

\begin{tabular}{ccccccc}
\hline Umur & $\begin{array}{c}\text { Jumlah Kuda } \\
\text { (n) }\end{array}$ & $\begin{array}{c}\text { Jenis } \\
\text { Kelamin }\end{array}$ & Nilai Korelasi & t Hitung & \multicolumn{2}{c}{ t Tabel } \\
\hline 2 & 36 & 0 & 0,894 & $11.696^{* *}$ & 2,042 & 2,750 \\
& 15 & + & 0,911 & $7,994^{* *}$ & 2,160 & 3,012 \\
3 & 31 & 0 & 0,961 & $18,785^{* *}$ & 2,045 & 2,756 \\
& 19 & + & 0,878 & $7,595^{* *}$ & 2,110 & 2,808 \\
4 & 38 & 0 & 0,91 & $13,954^{* *}$ & 2,042 & 2,750 \\
& 21 & + & 0,927 & $10,817^{* *}$ & 2,093 & 2,861 \\
5 & 27 & 0 & 0,760 & $5,847^{* *}$ & 2,060 & 2,787 \\
& 15 & 0 & 0,772 & $4,382^{* *}$ & 2,160 & 3,012 \\
\hline
\end{tabular}

Keterangan : $* *$ sangat nyata $(\mathrm{P}<0,01)$

Pengaruh lingkungan dan pengaruh genetis pada kuda jantan dan kuda betina dapat dilihat pada Tabel 6. Pada penelitian ini mengindikasikan bahwa pada kuda pacu jantan dan betina pengaruh lingkunganlah lebih besar dibandingkan pengaruh genetis. Tapi pada pengaruh genetis nilai kuda pacu betina yang lebih tinggi dari pada kuda pacu jantan. Nilai ripitabilitas tinggi badan kuda pacu dapat dilihat pada Tabel 7. Tabel 7 menunjukkan bahwa betina lebih tinggi dibandingkan dengan kuda pacu jantan.

Bowling dan Ruvinsky (2004) melaporkan analisis hubungan antara koformasi dan karakteristik kecepatan lari pada anak kuda. Peningkatan kecepatan anak kuda disebabkan pertambahan panjang langkah. Anak kuda berkecepatan lari tinggi memiliki kaki yang lebih berat, melangkah lebih tinggi dengan frekuensi langkah yang lebih banyak. Hal ini terjadi pada kuda-kuda yang relatif lebih tinggi pada penelitian ini, pendugaan nilai korelasi antara kecepatan lari dan tinggi pundak dilakukan berdasarkan pernyataan Bowling dan Ruvinsky (2004) bahwa tinggi badan merupakan faktor penentu kecepatan lari kuda pacu. Hasil pendugaan nilai korelasi antara sifat kecepatan lari dan tinggi pundak disajikan pada Tabel 8. Tabel 8 menjelaskan bahwa nilai korelasi 
antara sifat kecepatan lari dan tinggi pundak pada kuda pacu umur 2 sampai 5 tahun memiliki nilai korelasi yang sangat nyata, karena nilai t hitung lebih besar dari pada nilai $\mathrm{t}$ tabel 0,05 dan 0,01 . Jadi kecepatan lari seekor kuda mempunyai hubungan dengan tinggi pundak seekor kuda. Performa kuda pacu Indonesia dipengaruhi perkembangan otot yang lebih sempurna disamping pelatihan yang rutin. Thomson (1995) menyatakan kuda memiliki perototan yang terdiri atas 3 jenis urat syaraf utama, yaitu slow twitch fiber yang mempengaruhi kekuatan dan daya tahan otot, intermediate twitch fiber yang mempengaruhi kemampuan kedua urat syaraf lain dan fast twitch fiber yang mempengaruhi kecepatan kontraksi otot.

\section{KESIMPULAN}

Berdasarkan hasil penelitian dapat disimpulkan bahwa kecepatan lari kuda pacu jantan dan betina meningkat seiring dengan bertambah umur dan penurunan kecepatan lari kuda pacu terjadi karena waktu dan frekuensi latihan berkurang akibat penerapan program manajemen reproduksi, di samping jumlah yang disertakan dalam pacuan menurun. Peternak mulai mengikut sertakan kuda mereka dalam pacuan saat kuda berumur 2 tahun, karena pada umur tersebut sudah memiliki performa dan layak disertakan dalam pacuan. Pengaruh lingkungan sementara yang ditunjukan oleh nilai ripitabilitas kecepatan lari kuda pacu jantan dan betina lebih tinggi dibandingkan faktor genetis.

\section{DAFTAR PUSTAKA}

Astuti, V.D. 2011. Ripitabilitas Sifat Kemampuan Kuda Pacu Indonesia Mempertahankan Kecepatan Berlari. Tesis. Institut Pertanian Bogor, Bogor.

Becker, W. A. 1968. Manual of Procedures in Quantitative Gentics. $2^{\text {nd }}$ Ed. Washington State Universty Press, Washington

Bowling, A.T. A. Ruvnsky. 2004. The Genetics of the Horse. CABI Publishing London

Ekiz B, and Kocak O. 2007. Estimated of genetic parameters for racing times of Thoroughbred horses. Truk $J$ vet Anim Sci. 31 (1) : 1-5

Hintz, R. L. 1980. Genetic of Performance in the Horse. J. Anim. Sci. 51:582594

Islami, R. Z. 2006. Evaluasi Performa Kuda Pacu Indonesia. Tesis. Sekolah Pascasarjana, Institut Pertanian Bogor, Bogor

Kurnianto, E. 2009. Pemuliaan Ternak. Catatan Pertama, Penerbit Graha Ilmu. Yogyakarta.

Noor, R.R. 2008. Genetika Ternak. Cetakan ke-4. Penebar swadaya, Jakarta. 
Thompson, K. N. 1995. Skeletal Growth Rates of Weanling and Yearling Thoroughbred Horses. J. Anim. Sci. 73:2513-2517

Turner, H. N. dan S. Young. 1969. Quantitative Genetics in Sheep
Breeding. CornellUniversity Press, New York

Warwick, E.J., J. Maria Astuti dan W. Harjosubroro. 1987. Pemuliaan Ternak Gadjah Mada University press, Yogyakarta. 